\section{Outcome after relapse of myelodysplastic syn- drome and secondary acute myeloid leukemia following allogeneic stem cell transplantation: a retrospective registry analysis on 698 patients by the Chronic Malignancies Working Party of the European Society of Blood and Marrow Transplantation}

\author{
Christoph Schmid, ${ }^{1 *}$ Liesbeth C. de Wreede, ${ }^{2,3}$ * Anja van Biezen, ${ }^{2}$ Jürgen \\ Finke, ${ }^{4}$ Gerhard Ehninger, ${ }^{5}$ Arnold Ganser, ${ }^{6}$ Liisa Volin, ${ }^{7}$ Dietger Niederwieser, ${ }^{8}$ \\ Dietrich Beelen, ${ }^{9}$ Paolo Alessandrino, ${ }^{10}$ Lothar Kanz, ${ }^{11}$ Michael Schleuning, ${ }^{12}$ \\ Jakob Passweg, ${ }^{13}$ Hendrik Veelken, ${ }^{14}$ Johan Maertens, ${ }^{15}$ Jan J. Cornelissen, ${ }^{16}$ \\ Didier Blaise, ${ }^{17}$ Martin Gramatzki, ${ }^{18}$ Noel Milpied, ${ }^{19}$ Ibrahim Yakoub-Agha, ${ }^{20}$ \\ Ghulam Mufti, ${ }^{21}$ Montserrat Rovira, ${ }^{22}$ Renate Arnold, ${ }^{23}$ Theo de Witte, ${ }^{24}$ \\ Marie Robin ${ }^{25}$ and Nikolaus Kröger ${ }^{26}$
}

${ }^{1}$ Department of Hematology and Oncology, Klinikum Augsburg, University of Munich, Augsburg, Germany; ${ }^{2}$ Department of Medical Statistics \& Bioinformatics, Leiden University Medical Center, the Netherlands; ${ }^{3}$ DKMS, German Bone Marrow Donor Center, Germany; ${ }^{4}$ Department of Medicine 1, Hematology and Oncology, University of Freiburg, Germany; ${ }^{5}$ Medizinische Klinik und Poliklinik I, Universitaets-Klinikum Dresden, Germany; ${ }^{6}$ Department of Hematology, Hemostasis, Oncology and Stem Cell Transplantation, Hannover Medical School, Germany; ${ }^{7}$ Stem Cell Transplantation Unit, $\mathrm{HUCH}$ Comprehensive Cancer Center, Helsinki, Finland; ${ }^{8}$ Division of Hematology, Oncology and Hemostaseology, University Hospital Leipzig, Germany; 'Department of Bone Marrow Transplantation, University Hospital, Essen, Germany; ${ }^{10} \mathrm{Clinica}$ Ematologica, Fondazione IRCCS Policlinico San Matteo, Pavia, Italy; ${ }^{11}$ Medizinische Klinik II, Universität Tübingen, Germany; ${ }^{12} \mathrm{KMT}$ Zentrum, Deutsche Klinik für Diagnostik, Wiesbaden, Germany; ${ }^{13}$ Department of Hematology, University Hospital, Basel, Switzerland; ${ }^{14}$ BMT Center Leiden, Leiden University Hospital, the Netherlands;

${ }^{15}$ Department of Hematology, University Hospital Gasthuisberg, Leuven, Belgium;

${ }^{16}$ Erasmus MC Cancer Institute, University Medical Center Rotterdam, the Netherlands; ${ }^{17}$ Centre de Recherche en Cancérologie de Marseille, Institut Paoli Calmettes, Marseille, France; ${ }^{18}$ Division of Stem Cell Transplantation and Immunotherapy, University Hospital Schleswig-Holstein Campus, Kiel, Germany; ${ }^{19} \mathrm{CHU}$ Bordeaux, Hôpital Haut-Leveque, Pessac, France; ${ }^{20} \mathrm{Hôpital} \mathrm{Huriez,} \mathrm{CHRU,} \mathrm{Lille,} \mathrm{France;}{ }^{21}$ Department of Hematological Medicine, GKT School of Medicine, London, UK; ${ }^{22}$ Institute of Hematology \& Oncology, Hospital Clinic, Barcelona, Spain; ${ }^{23}$ Medizinische Klinik m. S. Hämatologie/Onkologie, Charité Universitätsmedizin Berlin, Germany; ${ }^{24}$ Department of Tumor Immunology, Radboud University Medical Center, Nijmegen, the Netherlands; ${ }^{25}$ Department of Hematology - BMT, Hôspital St. Louis, Paris, France and ${ }^{26}$ Department of Stem Cell Transplantation, University Hospital Eppendorf, Hamburg, Germany

${ }^{*} \mathrm{CS}$ and LdW contributed equally to this manuscript

\section{ABSTRACT}

$\mathrm{N}$ standard exists for the treatment of myelodysplastic syndrome relapsing after allogeneic stem cell transplantation. We performed a retrospective registry analysis of outcomes and risk factors in 698 patients, treated with different strategies. The median overall survival from relapse was 4.7 months (95\% confidence interval: 4.1-5.3) and the 2-year survival rate was $17.7 \%$ (95\% confidence interval: 14.8$21.2 \%)$. Shorter remission after transplantation $(P<0.001)$, advanced disease $(P=0.001)$, older age $(P=0.007)$, unrelated donor $(P=0.008)$ and acute graft-versus-host disease before relapse $(P<0.001)$ adversely influenced survival. At 6 months from relapse, patients had received no cellular treatment, (i.e. palliative chemotherapy or best supportive care, $n=375$ ), donor lymphocyte infusion $(n=213)$, or a second transplant $(n=110)$. Treatment groups were analyzed separately because of imbalanced characteristics and difficulties in retrospectively evaluating the reason for individual treatments. Of the patients who did not receive any cellular therapy, 109 were alive at 6 months after relapse, achieving a median

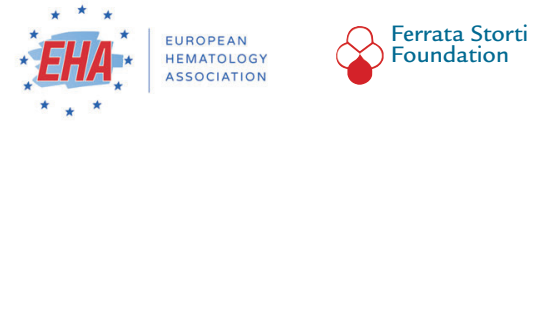

Haematologica 2018

Volume 103(2):237-245

\section{Correspondence: \\ christoph.schmid@klinikum-augsburg.de}

Received: March 13, 2017.

Accepted: October 30, 2017.

Pre-published: November 3, 2017.

doi:10.3324/haematol.2017.168716

Check the online version for the most updated information on this article, online supplements, and information on authorship \& disclosures: www.haematologica.org/content/103/2/237

\section{(C)2018 Ferrata Storti Foundation}

Material published in Haematologica is covered by copyright. All rights are reserved to the Ferrata Storti Foundation. Use of published material is allowed under the following terms and conditions:

https://creativecommons.org/licenses/by-nc/4.0/legalcode. Copies of published material are allowed for personal or internal use. Sharing published material for non-commercial purposes is subject to the following conditions:

https://creativecommons.org/licenses/by-nc/4.0/legalcode, sect. 3. Reproducing and sharing published material for commercial purposes is not allowed without permission in writing from the publisher. 
overall survival from this landmark of 8.9 months (95\% confidence interval: 5.1-12.6). Their 2-year survival rate was $29.7 \%$. Recipients of donor lymphocytes achieved a median survival from first infusion of 6.0 months (95\% confidence interval: 3.7-8.3) with a 2-year survival rate of $27.6 \%$. Longer remission after first transplantation $(P<0.001)$ and younger age $(P=0.009)$ predicted better outcome. Among recipients of a second transplant, the median survival from second transplantation was 4.2 months ( $95 \%$ confidence interval: 2.5-5.9), and their 2-year survival rate was 17.0\%. Longer remission after first transplantation $(P<0.001)$, complete remission at second transplant $(P=0.008)$, no prior chronic graft-versus-host disease $(P<0.001)$ and change to a new donor $(P=0.04)$ predicted better outcome. The data enabled identification of patients benefiting from donor lymphocyte infusion and second transplantation, and may serve as a baseline for prospective trials.

\section{Introduction}

Relapse of the underlying disease is a major drawback of allogeneic hematopoietic stem cell transplantation (HSCT) for myelodysplastic syndrome (MDS) and secondary acute myeloid leukemia (sAML) evolved from MDS, in particular as a consequence of the increasing numbers of HSCT with reduced intensity conditioning. ${ }^{1,2}$ As in other diseases, there is no defined standard approach to the management of post-transplant relapse. ${ }^{3}$ Several studies addressing the outcome of post-transplant relapse in different myeloid diseases have included patients with MDS. ${ }^{46}$ However, a specified analysis for MDS was usually not performed, or included only limited numbers of patients. Hence, no largescale analysis of risk factors, different treatment strategies and outcomes of MDS relapse after HSCT is available. The Chronic Malignancies Working Party (CMWP) of the European Society for Blood and Marrow Transplantation (EBMT) performed a retrospective, registry-based analysis on adults with hematological relapse after allogeneic HSCT. Data are intended to serve as a baseline and comparison for future trials using innovative approaches.

\section{Methods}

Inclusion criteria for patients from the CMWP registry comprised: (i) first allogeneic HSCT for MDS or sAML, using matched related, mismatched related or matched unrelated donors; (ii) age at HSCT $\geq 18$ years; (iii) first hematological relapse after transplant (excluding decreasing chimerism or cytogenetic/molecular relapse); and (iv) reliable documentation about the management of posttransplant relapse. Patients had agreed to reporting data to national and international registries before transplantation. The study was approved by the ethical committee of the Medical Faculty, University of Essen. All procedures complied with the ethical standards of the responsible committees (institutional and national) and the revised version of the Helsinki Declaration of 1975.

Based on the first treatment received during the first 6 months after relapse, three treatment groups were defined: (i) patients who did not receive any cellular therapy; (ii) patients who received donor lymphocyte infusion (DLI); and (iii) patients who underwent a second allogeneic HSCT (HSCT2). The 6-month cutoff was chosen, since $>95 \%$ of HSCT 2 and $>98 \%$ of DLI reported in published studies were performed within the first 6 months after relapse. Hence, the cumulative use of these strategies, as well as the outcome of patients treated without cellular therapy, could be studied. Patients who both received DLI and underwent a subsequent transplant proceeded to the DLI group, if HSCT2 was given $>90$ days after DLI, because 90 days were regarded as sufficient to evaluate the effect of DLI. Patients who received a second transplant $<90$ days after DLI entered the HSCT2 cohort, since HSCT was considered as the decisive intervention for the long-term outcome. Although being somewhat arbitrary, this classification enabled patients receiving both DLI and HSCT2 to be included in the analysis without uncontrolled bias. Conditioning, graft-versus-host disease (GvHD) ${ }^{8}$ and remission before $\mathrm{HSCT}^{9}$ were defined as described previously. As suggested $^{5}$, the transfusion of peripheral blood stem cells or bone marrow was defined as DLI, if no prior conditioning and no prophylactic immunosuppression was given, whereas HSCT2 was defined as infusion of donor peripheral blood stem cells or bone marrow following a conditioning regimen and with prophylactic immunosuppression (refer to the Online Supplement for details).

\section{Statistics}

Overall survival from relapse was the primary endpoint. ${ }^{10}$ Variables considered included characteristics of patients and their disease, donors, transplant procedure, and relapse (see the Online Supplement for details). Variables were compared among treatment groups, using the chisquare test for categorical variables and the Kruskal-Wallis test for continuous ones. In patients receiving DLI or HSCT2, cumulative incidence of relapse and non-relapse mortality were analyzed by competing risks models, with the starting time being the moment of DLI/HSCT2. In addition to the factors mentioned above, the characteristics of the DLI/HSCT2 were considered for risk analysis. Outcomes of subgroups were compared using a log-rank test. Cox proportional hazards regression models were used for multivariable analyses of factors for time-to-event endpoints. Variables were included if considered relevant based on the univariate analysis $(P$-value $<0.2)$, or known to be so from the literature. Patients with missing predictor data were included in the analysis by assigning them to separate categories of the pertaining variables. Hazard ratios (HR) and $95 \%$ confidence intervals $(95 \% \mathrm{CI}$ ) are reported. R Version 3.1.0, packages 'survival', 'cmprsk' and "mstate" ${ }^{11}$ and SPSS versions 18 and 23 (SPSS Inc. Chicago, IL, USA) were used.

\section{Results}

\section{Patients' characteristics and overall outcome}

A total of 698 patients fulfilled the inclusion criteria (Table 1). The median interval between HSCT and hema- 
tological relapse was 6.3 months (range, 1-160.8). The median follow-up from relapse among survivors was 9.4 months (range, 0.7-119.8). The median overall survival from relapse of the entire cohort was 4.7 months $(95 \%$ CI:
4.1-5.3 months). The overall survival rate was $27.6 \%$ (95\% CI: $24.2-31.3 \%)$ at 1 year, $17.7 \%$ (95\% CI: 14.8 $21.2 \%)$ at 2 years and $11.4 \%$ (95\% CI: $8.8-14.7 \%)$ at 4 years (Figure 1). Progression or another relapse of

Table 1. Baseline characteristics of 698 patients relapsing after allogeneic stem cell transplantation for myelodysplastic syndrome or secondary acute myeloid leukemia.

\begin{tabular}{|c|c|c|c|c|c|c|c|}
\hline & & $\begin{array}{l}\text { Entire } \\
\text { cohort }\end{array}$ & $\begin{array}{r}\text { Patie } \\
\text { no cel } \\
\text { Total }\end{array}$ & $\begin{array}{l}\text { ts receiving } \\
\text { ular therapy } \\
\text { Alive without cell. } \\
\text { therapy at } 6 \text { months } \\
\text { from relapse* }\end{array}$ & $\begin{array}{c}\text { Patients } \\
\text { given DLI } \\
\pm \text { prior } \\
\text { chemotherapy } \\
\text { as primary } \\
\text { intervention }\end{array}$ & $\begin{array}{c}\text { Patients } \\
\text { given a } \\
\text { second HSCT } \\
\pm \text { prior } \\
\text { chemotherapy } \\
\text { as primary intervention }\end{array}$ & $P$ \\
\hline Number of patients & & $\begin{array}{c}698 \\
(100 \%)\end{array}$ & $\begin{array}{c}375 \\
(54 \%)\end{array}$ & $\begin{array}{c}109 \\
(16 \%)\end{array}$ & $\begin{array}{c}213 \\
(31 \%)\end{array}$ & $\begin{array}{c}110 \\
(16 \%)\end{array}$ & \\
\hline $\begin{array}{l}\text { Year of HSCT, } \\
\text { (range) }\end{array}$ & & $\begin{array}{c}2003 \\
(1994-2008)\end{array}$ & $\begin{array}{c}2003 \\
(1994-2008)\end{array}$ & & $\begin{array}{c}2002 \\
(1994-2008)\end{array}$ & $\begin{array}{c}2002 \\
(1994-2008)\end{array}$ & 0.005 \\
\hline $\begin{array}{l}\text { Patients' age at relapse } \\
\text { (years) }\end{array}$ & $\begin{array}{l}\text { Median } \\
\text { (range) }\end{array}$ & $\begin{array}{c}52.2 \\
(18.4-74.9)\end{array}$ & $\begin{array}{c}53.3 \\
(18.4-73.3)\end{array}$ & $\begin{array}{c}51.4 \\
(21.3-72.3)\end{array}$ & $\begin{array}{c}52.3 \\
(18.7-74.9)\end{array}$ & $\begin{array}{c}48.7 \\
(20.7-68.3)\end{array}$ & 0.04 \\
\hline Patients' sex (n) & $\begin{array}{l}\text { Female } \\
\text { Male }\end{array}$ & $\begin{array}{l}328(47 \%) \\
370(53 \%)\end{array}$ & $\begin{array}{l}164(44 \%) \\
211(56 \%)\end{array}$ & $\begin{array}{l}44(40 \%) \\
65(60 \%)\end{array}$ & $\begin{array}{l}116(55 \%) \\
97(46 \%)\end{array}$ & $\begin{array}{l}48(44 \%) \\
62(56 \%)\end{array}$ & 0.03 \\
\hline $\begin{array}{l}\text { Time from diagnosis } \\
\text { to HSCT (months) }\end{array}$ & $\begin{array}{l}\text { Median } \\
\text { (range) }\end{array}$ & $\begin{array}{c}6.5 \\
(0.4-291.6)\end{array}$ & $\begin{array}{c}7.0 \\
(0.4-291.6)\end{array}$ & $\begin{array}{c}7.3 \\
(1.0-291.6)\end{array}$ & $\begin{array}{c}6.2 \\
(0.8-143.2)\end{array}$ & $\begin{array}{c}5.5 \\
(0.8-104.7)\end{array}$ & 0.001 \\
\hline Diagnosis at HSCT (n) & $\begin{array}{l}\text { RA/RARS } \\
\text { RAEB } \\
\text { sAML** } \\
\text { Missing }\end{array}$ & $\begin{array}{c}47(8 \%) \\
107(19 \%) \\
418(73 \%) \\
126\end{array}$ & $\begin{array}{c}24(8 \%) \\
48(16 \%) \\
231(76 \%) \\
72\end{array}$ & $\begin{array}{c}14(17 \%) \\
15(18 \%) \\
53(65 \%) \\
27\end{array}$ & $\begin{array}{c}19(11 \%) \\
39(22 \%) \\
121(68 \%) \\
34\end{array}$ & $\begin{array}{c}4(4 \%) \\
20(22 \%) \\
66(73 \%) \\
20\end{array}$ & 0.12 \\
\hline $\begin{array}{l}\text { Stage at HSCT } \\
(\mathrm{n}, \%)\end{array}$ & $\begin{array}{l}\text { Untreated } \\
\text { CR } \\
\text { Relapse/ } \\
\text { progression } \\
\text { rimary refractory }\end{array}$ & $\begin{array}{c}144(21 \%) \\
304(44 \%) \\
77(11 \%) \\
173(25 \%)\end{array}$ & $\begin{array}{l}71(19 \%) \\
171(46 \%) \\
48(13 \%) \\
85(23 \%)\end{array}$ & $\begin{array}{l}29(27 \%) \\
42(39 \%) \\
15(14 \%) \\
23(21)\end{array}$ & $\begin{array}{c}51(24 \%) \\
84(39 \%) \\
18(9 \%) \\
60(28 \%)\end{array}$ & $\begin{array}{l}22(20 \%) \\
49(45 \%) \\
11(10 \%) \\
28(26 \%)\end{array}$ & 0.538 \\
\hline Donor (n, \%) & $\begin{array}{l}\text { Matched family } \\
\text { lismatched family } \\
\text { or unrelated }\end{array}$ & $\begin{array}{l}398(57 \%) \\
300(43 \%)\end{array}$ & $\begin{array}{l}190(51 \%) \\
185(49 \%)\end{array}$ & $\begin{array}{l}59(54 \%) \\
50(46 \%)\end{array}$ & $\begin{array}{l}135(63 \%) \\
78(37 \%)\end{array}$ & $\begin{array}{c}73(66 \%) \\
373(34 \%)\end{array}$ & 0.14 \\
\hline $\begin{array}{l}\text { Sex match donor/ } \\
\text { recipient }(n, \%)\end{array}$ & $\begin{array}{c}\text { Female in male } \\
\text { Other } \\
\text { Missing }\end{array}$ & $\begin{array}{c}117(17 \%) \\
571(83) \\
10\end{array}$ & $\begin{array}{c}72(20 \%) \\
296(80 \%) \\
7\end{array}$ & $\begin{array}{c}22(21 \%) \\
84(79 \%) \\
3\end{array}$ & $\begin{array}{c}27(13 \%) \\
183(87 \%) \\
3\end{array}$ & $\begin{array}{c}18(16 \%) \\
92(84 \%) \\
-\end{array}$ & 0.19 \\
\hline $\begin{array}{l}\text { Conditioning } \\
(\mathrm{n}, \%)\end{array}$ & $\begin{array}{l}\text { Standard } \\
\text { Reduced }\end{array}$ & $\begin{array}{l}413(59 \%) \\
285(41 \%)\end{array}$ & $\begin{array}{c}216(58) \\
159(42 \%)\end{array}$ & $\begin{array}{l}63(58 \%) \\
46(42 \%)\end{array}$ & $\begin{array}{l}128(60 \%) \\
85(40 \%)\end{array}$ & $\begin{array}{l}69(63 \%) \\
41(37 \%)\end{array}$ & 0.76 \\
\hline $\begin{array}{l}\text { T-cell depletion } \\
\text { before HSCT (n, \%) }\end{array}$ & $\begin{array}{c}\text { No } \\
\text { In vivo } \\
\text { Ex vivo } \\
\text { In vivo+ ex vivo } \\
\text { Missing }\end{array}$ & $\begin{array}{c}383(56 \%) \\
199(29 \%) \\
53(8 \%) \\
48(7 \%) \\
15\end{array}$ & $\begin{array}{c}213(58 \%) \\
106(29 \%) \\
27(7 \%) \\
20(6 \%) \\
9\end{array}$ & $\begin{array}{c}58(54 \%) \\
33(31 \%) \\
10(9 \%) \\
6(6 \%) \\
2\end{array}$ & $\begin{array}{c}106(51 \%) \\
66(31 \%) \\
19(9 \%) \\
19(9 \%) \\
3\end{array}$ & $\begin{array}{c}64(60 \%) \\
27(25 \%) \\
7(7 \%) \\
9(8 \%) \\
3\end{array}$ & 0.70 \\
\hline $\begin{array}{l}\text { Stem cell source } \\
\text { at HSCT }(n, \%)\end{array}$ & $\begin{array}{c}\text { BM } \\
\text { PBSC } \\
\text { Missing }\end{array}$ & $\begin{array}{c}176(26 \%) \\
515(75 \%) \\
7\end{array}$ & $\begin{array}{c}92(25 \%) \\
276(75 \%) \\
7\end{array}$ & $\begin{array}{c}36(34 \%) \\
71(66 \%) \\
2\end{array}$ & $\begin{array}{c}57(27 \%) \\
156(73 \%) \\
-\end{array}$ & $\begin{array}{c}27(25 \%) \\
83(76 \%) \\
-\end{array}$ & 0.29 \\
\hline $\begin{array}{l}\text { Acute GvHD grade 2-4 } \\
\text { after first HSCT }\end{array}$ & $\begin{array}{c}\text { No } \\
\text { Yes } \\
\text { Missing }\end{array}$ & $\begin{array}{c}538(79 \%) \\
141(21 \%) \\
19\end{array}$ & $\begin{array}{c}266(73 \%) \\
100(27 \%) \\
9\end{array}$ & $\begin{array}{c}82(77 \%) \\
24(23 \%) \\
3\end{array}$ & $\begin{array}{c}182(88 \%) \\
25(12 \%) \\
6\end{array}$ & $\begin{array}{c}90(85 \%) \\
16(15 \%) \\
4\end{array}$ & 0.05 \\
\hline $\begin{array}{l}\text { Chronic GvHD after first } \\
\text { HSCT }(n, \%)\end{array}$ & $\begin{array}{c}\text { No } \\
\text { Yes } \\
\text { Missing }\end{array}$ & $\begin{array}{c}394(73 \%) \\
143(27 \%) \\
161\end{array}$ & $\begin{array}{c}204(71 \%) \\
84(29 \%) \\
87\end{array}$ & $\begin{array}{c}60(64 \%) \\
34(36 \%) \\
15\end{array}$ & $\begin{array}{l}143(77 \%) \\
42(23 \%) \\
28\end{array}$ & $\begin{array}{c}47(73 \%) \\
17(27 \%) \\
46\end{array}$ & 0.06 \\
\hline $\begin{array}{l}\text { Remission duration } \\
\text { after HSCT (months) } \\
(\mathrm{n}, \%)\end{array}$ & $\begin{array}{c}\text { Median } \\
\text { (range) } \\
<6 \text { months } \\
6-12 \text { months } \\
>12 \text { months }\end{array}$ & $\begin{array}{c}6.3 \\
(1.0-160.8) \\
329(47 \%) \\
202(29 \%) \\
167(24 \%)\end{array}$ & $\begin{array}{c}5.8 \\
(1.0-160.8) \\
193(52 \%) \\
105(28 \%) \\
77(21 \%)\end{array}$ & $\begin{array}{c}9.6 \\
(1.3-160.8) \\
28(26 \%) \\
40(37 \%) \\
41(38 \%)\end{array}$ & $\begin{array}{l}\quad 6.6 \\
(1.0-148.3) \\
92(43 \%) \\
63(30 \%) \\
58(27 \%)\end{array}$ & $\begin{array}{c}7.1 \\
(1.7-134.9) \\
44(40 \%) \\
34(31 \%) \\
32(29 \%)\end{array}$ & 0.009 \\
\hline
\end{tabular}

HSCT: hematopoietic stem cell transplantation; RA: refractory anemia; RARS: refractory anemia with ring sideroblasts; RAEB: refractory anemia with excess of blasts; sAML: secondary acute myeloid leukemia. CR: complete remission. GvHD: graft-versus-host disease *The 'no cellular therapy' group contained patients who never received cellular therapy due to early death, as well as patients whose follow-up was not long enough to ascertain if they had received cellular therapy or not.To avoid bias, only those patients were included into the comparison among treatment cohorts, of whom it was certain that they survived for $\geq 6$ months from relapse and had not received any cellular treatment. ** Patients initially classified as having RAEB-T have been classified as having sAML, using the current WHO definition of AML ( $\geq 20 \%$ blasts in the bone marrow). 
MDS/sAML was the leading cause of death $(82.1 \%$ of deaths). The remaining deaths were from causes related to HSCT or cellular therapy (14.9\%), secondary malignancies $(0.7 \%)$ or other causes $(2.2 \%)$. A risk factor analysis for outcome after relapse was performed. Results from univariate analysis are shown in Online supplementary Table S1. Table 2 shows the results of the multivariate analysis for overall survival, based on variables available at the time of the relapse. In the multivariate model, a longer remission after HSCT ( $>12$ months, HR 0.4, and 6-12 months HR 0.6, $P<0.001)$, an earlier stage of MDS at time of HSCT (refractory anemia with excess blasts and sAML versus refractory anemia/refractory anemia with ring sideroblasts; HR 1.6 and 2.0, $P=0.001$ ), younger age at relapse (HR 1.01 per year, $P=0.005$ ), donor type (unrelated donor versus HLA-identical sibling, HR 1.3, $P=0.005)$ and no history of acute GvHD before relapse (HR 0.6, $P<0.001$ ) were associated with better overall survival from relapse.

\section{Outcome according to the treatment applied}

In the first 6 months from relapse after HSCT, 213 patients were reported to have received DLI, and 110 to have undergone HSCT2. The other 375 patients had not received any cellular treatment: 109 of these were still alive and in follow-up 6 months after their relapse. Since patients who died early after relapse or whose follow-up was short did not have enough time for the transition to one of the two other groups, the comparison among treatment groups was only based on patients still in the group not having received any cellular therapy at 6 months after relapse, to avoid bias due to the high early mortality that by definition had to take place in this group.

To assess the time-dependent probability of receiving a cellular intervention in the first 6 months after relapse, or remaining alive cellular-treatment free, a competing risks

Table 2. Multivariate analysis of risk factors for overall survival from relapse in 698 patients.

\begin{tabular}{|c|c|c|c|c|}
\hline & HR & & HR & $\boldsymbol{P}$ \\
\hline & for death & lower & upper & \\
\hline Donor type & & & & 0.005 \\
\hline HLA-identical sibling & 1 & & & \\
\hline $\begin{array}{l}\text { Unrelated/mismatched } \\
\text { relative }\end{array}$ & 1.3 & 1.1 & 1.5 & \\
\hline MDS subtype at HSCT & & & & 0.001 \\
\hline RA/RARS & 1 & & & \\
\hline RAEB & 1.6 & 1.0 & 2.48 & 0.035 \\
\hline sAML & 2.0 & 1.54 & 2.9 & $<0.001$ \\
\hline Acute GvHD before re & lapse* & & & $<0.001$ \\
\hline No & 1 & & & \\
\hline Yes & 1.6 & 1.3 & 1.92 & \\
\hline $\begin{array}{l}\text { Age at relapse } \\
\text { (as continuous variable, } \\
\text { per year) }{ }^{* *}\end{array}$ & 1.010 & 1.003 & 1.016 & 0.005 \\
\hline Remission after HSCT & & & & \\
\hline$<6$ months & 1 & & & $<0.001$ \\
\hline 6-12-months & 0.6 & 0.5 & 0.7 & $<0.001$ \\
\hline$>12$ months & 0.4 & 0.3 & 0.5 & $<0.001$ \\
\hline
\end{tabular}

HR: hazard ratio; CI: confidence interval; MDS: myelodysplastic syndrome; HSCT: hematopoiet ic stem cell transplantation; RA: refractory anemia; RARS: refractory anemia with ring sideroblasts; RAEB: refractory anemia with excess of blasts; sAML: secondary acute myeloid leukemia; GvHD: graft-versus-host disease. * Patients with missing data were retained in the analysis by assigning them to a separate category (hazard ratios not shown). **Impact of an age differ ence at relapse of (e.g.) 10 years translates into a hazard ratio of 1.10 . analysis, accounting also for loss from follow-up, was performed. All patients started in the cellular-treatment free group, and could subsequently proceed to one of the other groups. DLI, HSCT2 and death without any cellular therapy (whichever occurred first) were considered as competing events (Figure 2).

Patients' characteristics such as age or duration of remission after HSCT were significantly different among the three treatment groups (Table 1). Furthermore, treatment

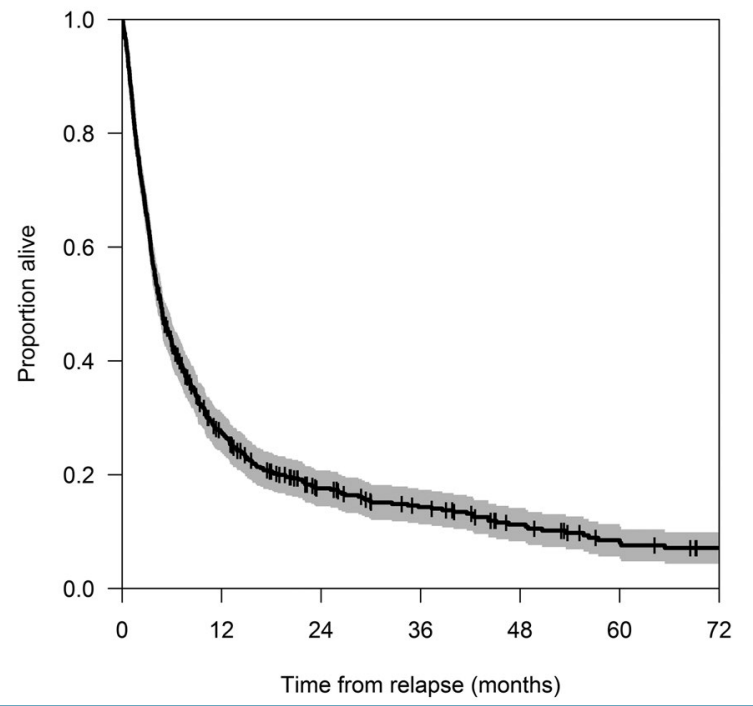

Figure 1. Overall survival from relapse in 698 patients. Overall survival (OS) from relapse of the entire cohort (gray area denotes 95\% confidence interval, $\mathrm{Cl}$, over time) The median overall survival was 4.7 months (95\% Cl: $4.1-5.3$ months).

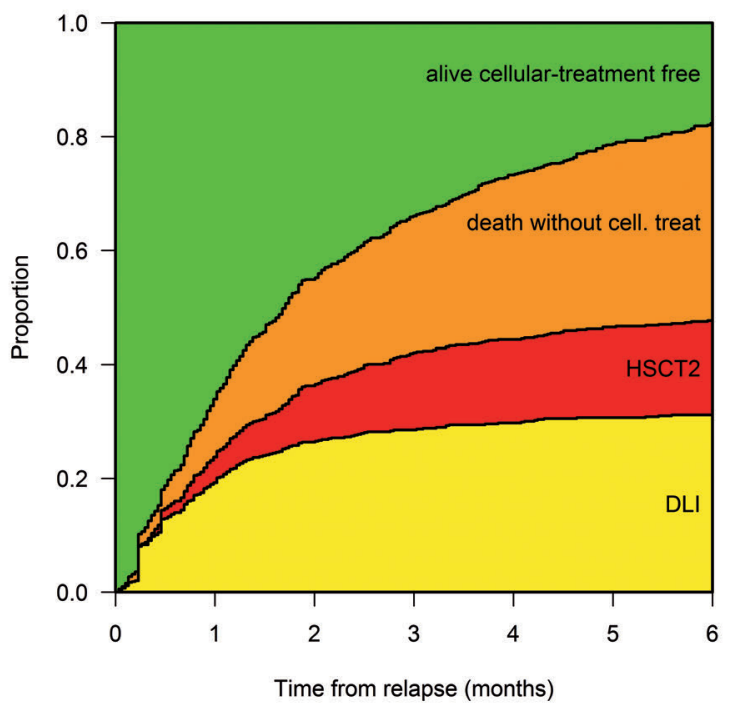

Figure 2. Cumulative incidence of treatments applied during the first 6 months. The plots are stacked: the distance between two lines (and, for the uppermost curve, the distance from the curve to $100 \%$ ) indicates the cumulative incidence as a function of time. At 6 months after relapse, the cumulative probability of having received a DLI (bottom group) was 31\% (95\% Cl: $28-35 \%$ ) and that of having undergone HCT2 (second group from the bottom) was $17 \%$ (95\% Cl: 14-19\%). Thirty-five percent had died without having received DLI or HSCT2 (second group from top), whereas 18\% (95\% Cl: 15-21\%) of patients were still in the cellular treatment-free group (uppermost group). 
decisions in the reporting centers had not been based on a general strategy, but had been made individually for each patient. Therefore, the reason for assigning a given patient to one of the treatment modalities could not be evaluated retrospectively at a reliable level. The three treatment cohorts were, therefore, evaluated separately, and no comparison of outcome was performed.

\section{Patients not receiving any cellular treatment $(n=375)$}

The treatment approaches applied among patients not receiving any cellular intervention ranged from palliation only to mild and intensive chemotherapy. However, detailed information on choice and dosage of the drugs used was not available. At last follow-up, 266 patients had died without having received DLI or HSCT2: reported causes of death were MDS/sAML in 92\%, and HSCTrelated events in $7 \%$. For the 109 patients alive at 6 months after relapse, the median overall survival from this landmark was 8.9 months (95\% CI: 5.1-12.6). The 2year overall survival rate was $29.7 \%$ (95\% CI: $20.1-$ $39.3 \%)$. Since the vast majority of DLI and HSCT2 had been given within the first 3 months after relapse, another landmark analysis was performed, including 221 patients who had been alive without any cellular therapy by day 90 . The median overall survival from this landmark was 6.1 months and the 2-year overall survival rate was $23.8 \%$

Patients receiving a second stem cell transplant $(\mathrm{n}=110)$

The characteristics of second transplants are shown in Table 3. Only $9 \%$ of patients underwent HSCT2 while in complete remission, whereas $90 \%$ had active disease. The median interval from relapse to HSCT2 was 1.7 months (range, 0.2-6.0). Seventy-six percent received the HSCT2 from the original donor, whereas a new donor was used in $24 \%$. Following HSCT2, 45 patients (46\% of informative cases) achieved complete remission; 16 of them developed another relapse at a median of 4.6 months (range, 1.8-37.8) after HSCT2. Acute GvHD grade II-IV and chronic GvHD developed in $24.8 \%$ and $34.6 \%$, respectively, of informative patients.

The median follow-up was 11.0 months among survivors. The median overall survival from HSCT2 was 4.2 months (95\% CI: 2.5-5.9), while the overall survival rates at 1,2 and 4 years were $22.3 \%$ (95\% CI: $13.9-30.7 \%$ ), $17.0 \%$ (95\% CI: $10.7-27.1 \%$ ) and $12.4 \%$ (95\% CI: $5.1-$ $19.7 \%$ ), respectively. (Figure 3A). The cumulative incidence of relapse/progression was 35\% (95\% CI: $26-45 \%$ ) at both 1 and 2 years, whereas the cumulative incidence of non-relapse mortality was $45 \%(95 \% \mathrm{CI}: 35-55 \%)$ at 1 year and $49.3 \%$ (95\% CI: $39-59 \%)$ at 2 years after HSCT2.

A risk factor analysis for overall survival from HSCT2 was performed, including variables known at the time of HSCT2. Results of the univariate analysis are provided in Online Supplementary Table S2. Among other factors, a history of DLI given prior to HSCT2 did not influence the overall outcome. In a multivariate Cox model (Table 4A) a sibling donor for HSCT1, no history of chronic GvHD after HSCT1, a longer remission after HSCT1, and HSCT2 in complete remission were strongly associated with better overall survival after HSCT2. With respect to disease stage, the median overall survival after HSCT2 in complete remission was 37.8 months, as compared to only 2.9 months after HSCT2 in active disease (univariate comparison). There was also an advantage for those patients undergoing HSCT2 from a different donor $(P=0.044$, HR 0.562 , 95\% CI: $0.321-0.984)$. The role of remission duration $(P=0.002)$ and stage $(P=0.022$; univariate KaplanMeier estimates) is illustrated in Figure 3B,C.

Patients receiving donor lymphocyte infusion $(n=213)$

The median interval from relapse to first DLI was 21 days (range, 0-170). The initial cell dose was $1 \times 10^{7} \mathrm{CD}^{+}$ cells/kg (range, 0.3-187). Of the informative patients,

Table 3. Characteristics and early outcome of second transplant in 110 patients.

\begin{tabular}{|c|c|c|}
\hline Characteristics & & $\begin{array}{c}\mathrm{N} \\
\text { (range or } \%\end{array}$ \\
\hline Interval between HSCT1 and HSCT2 (months) & $\begin{array}{l}\text { Median } \\
\text { (range) }\end{array}$ & $\begin{array}{c}9.4 \\
(2.3-135.8)\end{array}$ \\
\hline Interval between relapse and HSCT2 (months) & $\begin{array}{l}\text { Median } \\
\text { (range) }\end{array}$ & $\begin{array}{c}1.7 \\
(0.2-6.0)\end{array}$ \\
\hline DLI given for relapse $<90$ days before HSCT2 & $\begin{array}{c}\text { N. }(\%) \\
\text { Days between DLI } \\
\text { and HSCT2 } \\
\text { (median, range) }\end{array}$ & $12(11 \%)$ \\
\hline Stage at HSCT2, n (\%) & $\begin{array}{c}\text { CR } \\
\text { Active disease } \\
\text { Missing }\end{array}$ & $\begin{array}{c}9(10 \%) \\
85(90 \%) \\
16\end{array}$ \\
\hline Donor for HSCTl & $\begin{array}{l}\text { HLA identical family } \\
\text { Unrelated/mismatched } \\
\text { family }\end{array}$ & $\begin{array}{l}73(66 \%) \\
37(34 \%)\end{array}$ \\
\hline Donor for HSCT2 & $\begin{array}{l}\text { HLA identical family } \\
\text { Unrelated/mismatched } \\
\text { family } \\
\text { Missing }\end{array}$ & $\begin{array}{c}70(64 \%) \\
39(36 \%) \\
1\end{array}$ \\
\hline Donor change* from HSCT1 to HSCT2, n (\%) & $\begin{array}{c}\text { Same donor for HSCT2 } \\
\text { New donor for HSCT2 } \\
\text { Missing }\end{array}$ & $\begin{array}{c}83(76 \%) \\
26(24 \%) \\
1\end{array}$ \\
\hline Conditioning for HSCT2, n (\%) & $\begin{array}{l}\text { Standard } \\
\text { Reduced } \\
\text { Missing }\end{array}$ & $\begin{array}{c}46(43 \%) \\
61(57 \%) \\
3\end{array}$ \\
\hline TBI for conditioning before HSCT2 & $\begin{array}{c}\text { Yes } \\
\text { No } \\
\text { Missing }\end{array}$ & $\begin{array}{c}24(23 \%) \\
80(77 \%) \\
6\end{array}$ \\
\hline Source of stem cells for HSCT2 & $\begin{array}{c}\text { BM } \\
\text { PB9 } \\
\text { BM+PB } \\
\text { Cord blood } \\
\text { Missing }\end{array}$ & $\begin{array}{c}8(7 \%) \\
8(91 \%) \\
1(1 \%) \\
1(1 \%) \\
2\end{array}$ \\
\hline \multicolumn{3}{|l|}{ Outcome } \\
\hline Engraftment, n (\%) & $\begin{array}{c}\text { Yes } \\
\text { Yes, but secondary } \\
\text { graft failure } \\
\text { No } \\
\text { Missing }\end{array}$ & $\begin{array}{c}80(79 \%) \\
2(2 \%) \\
\\
19(19 \%) \\
9\end{array}$ \\
\hline Time to neutrophil engraftment, days & Median (range) & $13(0-102)$ \\
\hline Time to platelet engraftment, days & Median (range) & $20(7-263)$ \\
\hline Response after HSCT2, n (\%) & $\begin{array}{c}\text { Early death** } \\
\text { CR } \\
\text { No CR } \\
\text { Unknown }\end{array}$ & $\begin{array}{c}16(16 \%) \\
45(46 \%) \\
37(38 \%) \\
12\end{array}$ \\
\hline
\end{tabular}

HSCT: hematopoietic stem cell transplantation; DLI: donor lymphocyte infusion; BM: bone marrow; PB: peripheral blood; CR: complete remission. *Either from a matched family to an unrelated donor or from one unrelated donor to another. ** Early death was defined as death $<1$ month from HSCT2 and without re-occurrence of myelodysplastic syndrome or secondary acute myeloid leukemia. 
$68.6 \%, 17.1 \%$ and $14.3 \%$ received one, two and three infusions, respectively. The median follow-up of the 50 patients alive at last contact was 18.2 months (range, 0.03105.1). Following DLI, acute GvHD grade 2-4 was observed in 14 patients (26.4\% of informative cases). Limited and extensive chronic GvHD were reported in 15 and 13 patients, respectively. While response rate to DLI was not reported for a considerable number of patients, the median overall survival from first DLI was $6.0 \pm 1.2$ months (95\% CI: 3.7-8.3); overall survival rates at 1, 2 and 4 years were $36.1 \pm 3.5 \%, 27.6 \pm 3.3 \%$ and $17.0 \pm 3.2 \%$, respectively
(Figure 4A). Reported causes of death were MDS/sAML $(81.7 \%)$, HSCT related causes $(12.4 \%)$, secondary malignancies $(2.6 \%)$, and other causes $(3.3 \%)$. Results of the univariate analysis of risk factors for overall survival from first DLI are provided in Online Supplementary Table S3. A multivariate Cox model revealed a longer remission after HSCT (most significant), younger age, and male sex as significant protective parameters (Table 4B). Some patients achieved long-term survival after receiving a second transplant following the failure of DLI. Figure $4 \mathrm{~B}$ illustrates the role of remission duration $(P<0.001$, univariate Kaplan-
A

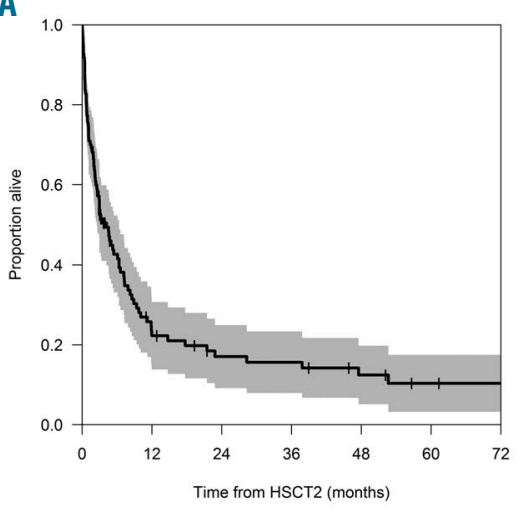

B

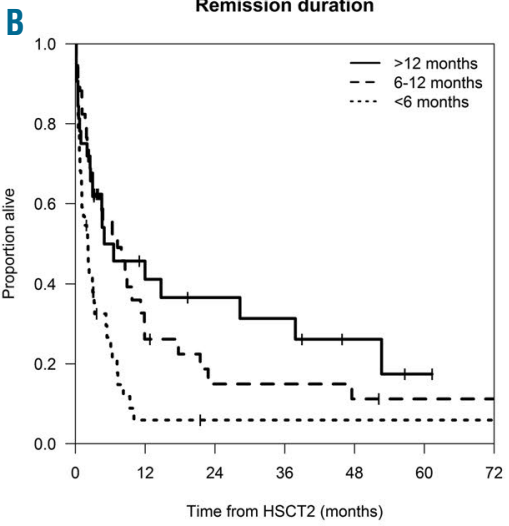

C

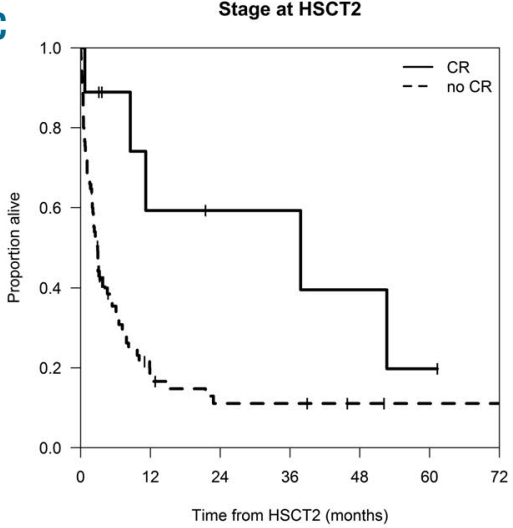

Figure 3. Overall survival after second transplant. (A) Within the entire cohort of 110 patients (gray area denotes $95 \%$ confidence interval, Cl, over time; 2 -year overall survival: 17.0, 95\% Cl: 10.7-27.1\%). (B) As of remission duration after first transplantation, (>12 months, solid line, 2-year overall survival 36.6\%, 95\% Cl: 21.9 61.0 ; 6-12 months, dashed line, 2-year overall survival 14.9\%, 95\% Cl: 6.3-35.7; <6 months, dotted line, 2-year overall survival 5.9\%, 95\% Cl: 15.7-22.3) $P=0.002$. (C) As of remission status at time of second transplant (complete remission, solid line, 2-year overall survival 59.3\%, 95\% Cl: 32.2-100\%; active disease, dotted line, 2-year OS 11.1\%, 95\% Cl: 5.5-22.4\%) $P=0.022$.

Table 4A. Multivariate analysis of risk factors for overall survival from second transplant in 110 patients.

\begin{tabular}{|c|c|c|c|c|}
\hline & $\begin{array}{c}\text { PR } \\
\text { for death }\end{array}$ & $\begin{array}{r}95 \\
\text { lower }\end{array}$ & $\begin{array}{l}\text { or HR } \\
\text { upper }\end{array}$ & $P$ \\
\hline $\begin{array}{l}\text { Donor type at HSCT1 } \\
\text { HLA-identical sibling } \\
\text { unrelated/mismatched }\end{array}$ & $\begin{array}{c}1 \\
1.8\end{array}$ & 1.1 & 2.9 & 0.018 \\
\hline $\begin{array}{l}\text { Cell source at HSCT1 } \\
\text { Bone marrow } \\
\text { Peripheral blood }\end{array}$ & $\begin{array}{c}1 \\
1.5\end{array}$ & 0.8 & 2.5 & 0.185 \\
\hline $\begin{array}{l}\text { Chronic GvHD before relapse* } \\
\text { No } \\
\text { Yes }\end{array}$ & $\begin{array}{c}* \\
1 \\
4.4\end{array}$ & 2.2 & 8.9 & $<.001$ \\
\hline $\begin{array}{l}\text { Remission after HSCT } \\
<6 \text { months } \\
<6 \text { months vs. } 6-12 \text { months } \\
<6 \text { months vs. }>12 \text { months }\end{array}$ & $\begin{array}{c}1 \\
0.5 \\
0.3\end{array}$ & $\begin{array}{l}0.3 \\
0.2\end{array}$ & $\begin{array}{l}0.8 \\
0.6\end{array}$ & $\begin{array}{c}<0.001 \\
0.003 \\
<0.001\end{array}$ \\
\hline $\begin{array}{l}\text { Stage at second HSCT* } \\
\text { Complete remission } \\
\text { Active disease }\end{array}$ & $\begin{array}{c}1 \\
3.8\end{array}$ & 1.49 & 10.4 & 0.008 \\
\hline $\begin{array}{l}\text { Donor change for HSCT2 } * \\
\text { Same donor for HSCT2 } \\
\text { Donor change for HSCT2 }\end{array}$ & $\begin{array}{c}1 \\
0.6\end{array}$ & 0.3 & 1.0 & 0.044 \\
\hline
\end{tabular}

HR: hazard ratio; CI: confidence interval; HSCT: hematopoietic stem cell transplantation; GvHD: graft-versus-host disease.
Table 4B. Multivariate analysis of risk factors for overall survival after first therapeutic donor lymphocyte infusion in 213 patients.

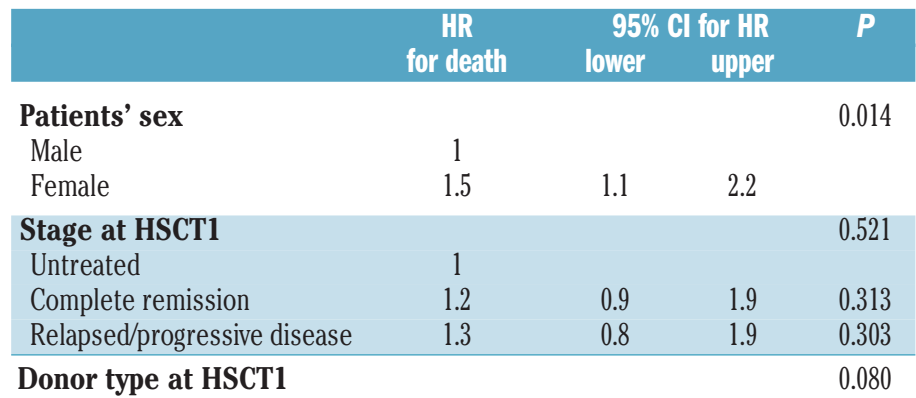

\begin{tabular}{lcccc}
$\begin{array}{l}\text { HLA-identical sibling } \\
\text { Unrelated/mismatched }\end{array}$ & 1 & & & \\
$\begin{array}{l}\text { Chronic GvHD before relapse* } \\
\text { No }\end{array}$ & 1.4 & 1.0 & 1.9 & \\
Yes & 1.0 & 0.6 & 1.6 & 0.904 \\
$\begin{array}{l}\text { Age at relapse } \\
\text { (as continuous variable, per year) }\end{array}$ & 1.017 & 1.004 & 1.030 & \\
$\begin{array}{l}\text { Remission after HSCT } \\
\text { < } 6 \text { months }\end{array}$ & 1 & & & $<0.009$ \\
6-12 months & 0.7 & 0.5 & 0.1 .0 & 0.048 \\
$>12$ months & 0.4 & 0.2 & 0.6 & $<.001$ \\
\hline
\end{tabular}

HR: hazard ratio; CI: confidence interval; HSCT: hematopoietic stem cell transplantation; GvHD graft-versus-host disease. *Patients with missing data were retained in the analysis by assigning them to separate categories (hazard ratios not shown). 
Meier estimate). If post-transplant remission exceeded 1 year, the median overall survival was 25.1 months $(95 \%$ CI: 8.4-41.8) and the 2 -year overall survival rate was $51.3 \%$ (95\% CI: 39.1-67.2\%).

\section{Discussion}

In the largest group of patients relapsing after allogeneic HSCT for MDS and sAML analyzed so far, less advanced stage of MDS at transplant (refractory anemia/refractory anemia with ring sideroblasts and refractory anemia with excess blasts versus sAML), no history of acute GvHD after HSCT, and a longer remission after HSCT were associated with better overall survival after relapse. At 2 and 4 years from relapse, $6 \%$ and $4 \%$ of patients, respectively, were alive without having received a cellular treatment. During the first 6 months after relapse, 31\% of patients were selected to receive DLI and $17 \%$ of patients received a second HSCT. The 2-year overall survival rates from the intervention in these selected subgroups were $28 \%$ for DLI recipients, and $17 \%$ for patients receiving HSCT2. While remission duration after HSCT1 was the most relevant prognostic parameter both after DLI and after HSCT2, no history of chronic GvHD after HSCT1, an HLA-identical family donor for HSCT1, and controlled disease at the time of HSCT2 were additional relevant factors for survival after a second transplant. Switching to an alternative donor for HSCT2 was associated with a better outcome.

Despite the large number of patients included in this analysis, the nature of a retrospective registry study implies several limitations. Most importantly, cytogenetic data were rather incomplete, thereby precluding calculation of the revised International Prognostic Scoring System score and the analysis of outcome and efficacy of different treatments in biologically defined risk groups. On the other hand, cytogenetics has not been found to play a major role in outcomes following post-transplant relapse either in $\mathrm{AML}^{12}$ or MDS (with the exception of very poor risk cytogenetic characteristics). ${ }^{13}$ Second, the analysis is based on patients transplanted in the past, for whom sufficient data of reasonable quality to perform such a detailed analysis were available. To study a possible change in outcome of post-transplant MDS relapse over time, we analyzed overall survival after relapse in a more recent cohort of MDS patients, also derived from the EBMT registry (transplantation years 2009-2012). The outcomes of this cohort were almost identical to those of our current study [median overall survival 5.0 months, 2-year overall survival rate 19\% (95\% CI 16 $21 \%$ ), data not shown in detail]. Similarly, the 2-year overall survival rate following post-HSCT relapse was $16 \%$ in a more recent smaller study ${ }^{13}$ which compares very well with our observation. We, therefore, believe that our data are still valid for current patients, also illustrating the limited progress made in recent years in the treatment of MDS relapsing after allogeneic HSCT, and the urgent need for new concepts. As discussed below, the broader use of hypomethylating agents might be a way to improve outcomes in the future. However, so far this has not been demonstrated in the various registry analyses.

The lack of precise data on disease status at the time of relapse prevented distinguishing between relapse as MDS versus sAML. This is another drawback of the analysis, since bone marrow infiltration by leukemic blasts at the time of relapse was a relevant factor for overall survival in a recent analysis on patients relapsing after reduced intensity conditioning HSCT for de novo AML ${ }^{14}$ The percentage of bone marrow blasts at relapse might also have influenced the treatment approach after relapse. The reason why no cellular therapy, DLI or a second transplant was preferred in a given patient could not be determined retrospectively. Given the differences in patients' characteristics among the three treatment groups, and because the group not given cellular therapy was a heterogeneous mixture of patients who died early, patients with a short follow-up and patients alive and truly untreated with DLI or HSCT2, we decided to limit the overall analysis of risk factors to variables that were known at the time of relapse, and performed separate studies for the DLI and HSCT2 subgroups. Hence, general conclusions for selecting treatment strategies cannot be drawn on the basis of this analysis.

As shown in many studies on relapse after allogeneic HSCT, ${ }^{5 ; 12 ; 14-17}$ remission duration after HSCT was the most important variable for outcome, irrespective of the applied treatment strategy. Patients with a history of acute GvHD after HSCT1 had an inferior outcome, a finding that has
A

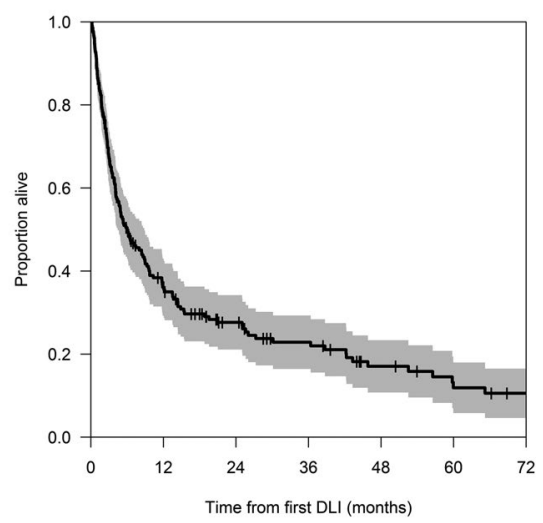

B

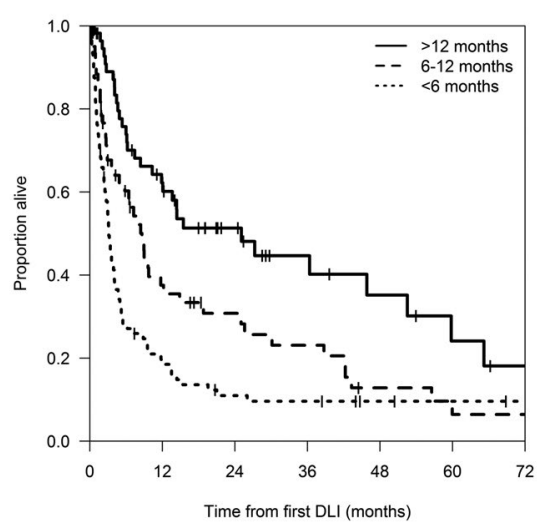

Figure 4. Overall survival after first therapeutic donor lymphocyte infusion. (A) Within the entire cohort of 213 patients, 2 year overall survival was $27.6 \%, 95 \%$ confidence interval $(\mathrm{Cl})$ : 21.1-34.1.0\%. Grey area denotes $95 \% \mathrm{Cl}$, over time (B) As of remission duration after HSCT1 $(>12$ months, solid line, 2-year overall survival 51.3\%, 95\% Cl: 39.1-67.2\%; 6-12 months, dashed line, 2-year overall survival 30.8\%, 95\% Cl: 20.2-46.8\%; <6 months, dotted line, 2 -year overall survival $11.0 \%, 95 \% \mathrm{Cl}$ : 5.9-20.4\%) $P<0.001$. 
similarly been reported after relapse from reducing intensity conditioning HSCT for de novo $\mathrm{AML}^{14}$ and acute lymphocytic leukemia, ${ }^{17}$ and in a recent French study on relapsed MDS. ${ }^{13}$ However, in our cohort, $23 \%$ of patients who did not receive any cellular therapy for post-transplant relapse had developed acute GvHD of grade II-IV after HSCT1, in contrast to only $12 \%$ and $15 \%$ among patients who received DLI or HSCT2, respectively $(P=0.05)$. Hence, a history of acute GvHD might not necessarily be a risk factor as such, but may have contributed to the decision not to consider DLI or HSCT2 in a given patient, or may have been associated with an inferior performance at the time of relapse, leading to less intensive treatment. Similarly, the history of a related donor transplant may have influenced the application of a donor cell based strategy (i.e. DLI or second transplant), and younger age may have been a criterion for offering HSCT2.

Precise information on 110 patients undergoing HSCT2 allowed for a detailed analysis of this strategy. The role of disease control before HSCT2 was a striking observation. Although only $10 \%$ of patients received HSCT2 in complete remission, stage at HSCT2 was a significant factor for outcome in multivariate analysis, and median overall survival after HSCT2 in complete remission was 37 months, as compared to only 2 months after HSCT2 in active disease (Figure 3B; the large confidence intervals underscoring the need for confirmatory studies). Nevertheless, selection of patients during and after chemotherapy precludes firm recommendations. Similar results have been reported recently in a large German study on HSCT2 for acute leukemia in the related and unrelated donor setting, ${ }^{18}$ and in an EBMT analysis on DLI for post-transplant relapse of de novo AML. ${ }^{10}$ Unfortunately, data on remission status at time of DLI in our study were not sufficient to reproduce these findings among DLI recipients.

Switching to a different donor for HSCT2 showed a limited, although statistically significant, advantage for overall survival (HR: 0.562, 95\% CI: 0.321-0.984 in the multivariate model). This observation is in line with those of several studies addressing this issue in acute leukemia, ${ }^{16,18}$ indicating that a change of donor is definitely not disadvantageous, and seems to offer a slight improvement in certain subgroups. Hence, our data add to the growing evidence, that changing to another donor is a justifiable option for HSCT2. Donor switching might be more promising among patients receiving HSCT2 for controlled disease, whereas in patients with a short post-transplant remission or in uncontrolled disease, the aggressiveness of the underlying malignancy will most likely overwhelm a putatively improved graft-versus-leukemia reaction of a new donor. Change to a haploidentical family donor might be another option, given the more rapid availability and the greater HLA disparity. ${ }^{19}$
Finally, patients without a history of chronic GvHD after HSCT1 had a better outcome after HSCT2, suggesting that in these patients, the graft-versus-leukemia effect might not yet have been exploited before post-transplant relapse.

In summary, we provide data on a large cohort of consecutively reported patients with relapsed MDS and sAML after allogeneic HSCT, discussing the difficulties and limitations of such a retrospective registry analysis. As in a recent French study, which showed comparable overall results in a smaller cohort, ${ }^{13}$ relapse or progression was by far the leading cause of death, underscoring the need for innovative strategies. Without a graft-versus-leukemiabased intervention (i.e., DLI or HSCT2), only a few patients survive more than 2 years after relapse. In contrast, DLI or second HSCT showed certain, albeit still limited, efficacy in selected patients, such as patients in whom the interval between HSCT and relapse was long, or patients who responded to chemotherapy. In the EBMT analysis on AML relapse after reduced intensity conditioning HSCT, a donor cell-based intervention was shown to be mandatory for long-term remission even in these positively selected patients. ${ }^{14}$ Similar findings emerged from the French study on post-HSCT MDS relapse mentioned above. In contrast, patients in whom the interval between HSCT and relapse is short or patients with overt AML and high blast counts have a grim prognosis and are not likely to benefit from the traditional interventions after relapse. Our results may serve as a baseline to which new approaches can be compared, as they give a large-scalebased estimate of the results to be expected after use of each approach in the treatment of MDS relapse after allogeneic HSCT. At present, hypomethylating agents (azacytidine, decitabine) alone or in combination with DLI seem to be among the most promising compounds for the treatment of post-transplant relapse in myeloid malignancies, ${ }^{20,21}$ because of both their direct antileukemic efficacy and their immunomodulatory capacity. ${ }^{22-26}$ Checkpoint inhibitors might be an option for the future. ${ }^{27}$ Strategies for prophylactic ${ }^{28-30}$ or preemptive $e^{31-33}$ treatment in highrisk patients are promising alternatives to avoid overt hematologic relapse, while targeting molecular aberrations such as Flt3-internal tandem duplication, or inhibition of histone deacetylase $e^{34}$ and prophylactic DLI are promising approaches to post-transplant maintenance.

\section{Acknowledgment}

Following EBMT publication rules, co-authorship was offered to centers contributing the highest number of patients. The authors also highly appreciate the contribution by many physicians and data managers throughout the EBMT, who made this analysis possible. A list of contributing centers and responsible physicians is provided in the Online Supplement.

\section{References}

1. Lim Z, Brand R, Martino R, et al. Allogeneic hematopoietic stem-cell transplantation for patients 50 years or older with myelodysplastic syndromes or secondary acute myeloid leukemia. J Clin Oncol. 2010;28(3):405-411.

2. McClune BL, Weisdorf DJ, Pedersen TL, et al. Effect of age on outcome of reduced- intensity hematopoietic cell transplantation for older patients with acute myeloid leukemia in first complete remission or with myelodysplastic syndrome. J Clin Oncol. 2010;28(11):1878-1887.

3. Platzbecker U. Who benefits from allogeneic transplantation for myelodysplastic syndromes?: new insights. Hematology Am Soc Hematol Educ Program. 2013;522-528.

4. Kolb HJ, Schattenberg A, Goldman JM, et al.
Graft-versus-leukemia effect of donor lymphocyte transfusions in marrow grafted patients. Blood. 1995;86(5):2041-2050

5. Levine JE, Braun T, Penza SL, et al Prospective trial of chemotherapy and donor leukocyte infusions for relapse of advanced myeloid malignancies after allogeneic stem-cell transplantation. J Clin Oncol. 2002;20(2):405-412.

6. Ruutu T, de Wreede LC, van Biezen A, et al. 
Second allogeneic transplantation for relapse of malignant disease: retrospective analysis of outcome and predictive factors by the EBMT. Bone Marrow Transplant. 2015;50(12):1542-1550.

7. Gratwohl A, Carreras E. Principles of Conditioning. In: Apperley JF, Carreras E, Gluckman E, Masszi T, eds. Haematopoietic Stem Cell Transplant. 2012:122-137.

8. Apperley JF, Masszi T. Graft-versus-host disease. In: Apperley JF, Carreras E, Gluckman E, Masszi T, eds. Haematopoietic Stem Cell Transplantation. 2012:217-247.

9. Cheson B, Benet JM, Kopecky KJ et al. Revised Recommendations of the International Working Group for Diagnostics, Standardization of Response Criteria, Treatment Outcomes, and Reporting Standards for Therapeutic Trials in Acute Myeloid Leukemia. J Clin Oncol. 2003;21(24):4642-4649.

10. Kaplan E, Meier P. Non parametric estimation from incomplete observatinons. J Am Stat Assoc. 1958:53:457-418.

11. de Wreede, LC, Fiocco, M, Putter, H. "mstate": An R package for the analysis of competing risk and multistate models. I Stat Software 2011;38(7):1-30

12. Schmid C, Labopin M, Nagler A, et al. Donor lymphocyte infusion in the treatment of first hematological relapse after allogeneic stem-cell transplantation in adults with acute myeloid leukemia: a retrospective risk factors analysis and comparison with other strategies by the EBMT Acute Leukemia Working Party. J Clin Oncol. 2007;25(31): 4938-4945.

13. Romain Guièze M, Damaj, G, Pereira, B, et al. Management of myelodysplastic syndrome relapsing after allogeneic hematopoietic stem cell transplantation: a study by the French society of bone marrow transplantation and cell therapies. Biol Blood Marrow Transplant. 2016;22(2):240-247.

14. Schmid C, Labopin M, Nagler A, et al. Treatment, risk factors, and outcome of adults with relapsed AML after reduced intensity conditioning for allogeneic stem cell transplantation. Blood. 2012;119(6): 1599-1606.

15. Bosi A, Laszlo D, Labopin M, et al. Second allogeneic bone marrow transplantation in acute leukemia: results of a survey by the European Cooperative Group for Blood and Marrow Transplantation. J Clin Oncol. 2001;19(16):3675-3684.

16. Eapen M, Giralt SA, Horowitz MM, et al.
Second transplant for acute and chronic leukemia relapsing after first HLA-identical sibling transplant. Bone Marrow Transplant. 2004;34(8):721-727.

17. Spyridonidis A, Labopin M, Schmid C, et al. Outcomes and prognostic factors of adults with acute lymphoblastic leukemia who relapse after allogeneic hematopoietic cell transplantation. An analysis on behalf of the Acute Leukemia Working Party of EBMT. Leukemia. 2012;26(6):1211-1217.

18. Christopeit M, Kuss O, Finke J, et al. Second allograft for hematologic relapse of acute leukemia after first allogeneic stem-cell transplantation from related and unrelated donors: the role of donor change. J Clin Oncol. 2013;31(26):3259-3271.

19. Tischer J, Engel N, Fritsch S, et a. Second haematopoietic SCT using HLA-haploidentical donors in patients with relapse of acute leukaemia after a first allogeneic transplantation. Bone Marrow Transplant. 2014;49(7): 895-901.

20. Jabbour E, Giralt S, Kantariian H, et al. Lowdose azacitidine after allogeneic stem cell transplantation for acute leukemia. Cancer 2009;115(9):1899-1905

21. Schroeder T, Czibere A, Platzbecker U, et al. Azacitidine and donor lymphocyte infusions as first salvage therapy for relapse of AML or MDS after allogeneic stem cell transplantation. Leukemia. 2013;27(6):1229 1235.

22. Rohner A, Langenkamp U, Siegler U, Kalberer CP, Wodnar-Filipowicz A. Differentiation-promoting drugs up-regulate NKG2D ligand expression and enhance the susceptibility of acute myeloid leukemia cells to natural killer cell-mediated lysis. Leuk Res. 2007;31(10)1393-1402.

23. Goodyear O, Agathanggelou A, NovitzkyBasso I, et al. Induction of a CD8+ T-cell response to the MAGE cancer testis antigen by combined treatment with azacitidine and sodium valproate in patients with acute myeloid leukemia and myelodysplasia. Blood. 2010;116(11):1908-1918.

24. Goodyear OC, Dennis M, Jilani NY, et al Azacitidine augments expansion of regulatory $\mathrm{T}$ cells after allogeneic stem cell transplantation in patients with acute myeloid leukemia (AML). Blood. 2012;119(14):33613369.

25. Schroeder T, Frobel J, Cadeddu RP, et al. Salvage therapy with azacitidine increases regulatory $\mathrm{T}$ cells in peripheral blood of patients with AML or MDS and early relapse after allogeneic blood stem cell transplantation. Leukemia. 2013;27(9):1910-1913

26. Craddock C, Jilani N, Siddique $S$, et al Tolerability and clinical activity of posttransplantation azacitidine in patients allografted for acute myeloid leukemia treated on the RICAZA trial. Biol Blood Marrow Transplant. 2016;22(2):385-390.

27. Davids MS, Kim HT, Bachireddy P, et al. Ipilimumab for Patients with Relapse afte allogeneic transplantation. N Engl J Med. 2016;375(2):143-153.

28. de Lima M, Bonamino M, Vasconcelos Z Prophylactic donor lymphocyte transfusion after moderately ablative chemotherapy and stem cell transplantation for hematological malignancies: high remission rate at the expense of of graft-versus-host disease. Bone Marrow Transplant. 2001;27(1):73-78.

29. Barge RM, Osanto S, Marijt WA, et al Minimal GVHD following in-vitro $T$ celldepleted allogeneic stem cell transplantation with reduced-intensity conditioning allowing subsequent infusions of donor lymphocytes in patients with hematological malignancies and solid tumors. Exp Hematol. 2003:31(10):865-872.

30. Jedlickova Z, Schmid C, Koenecke C, et al Long-term results of adjuvant donor lymphocyte transfusion in AML after allogeneic stem cell transplantation. Bone Marrow Transplant. 2016;51(5):663-667

31. de Lima M, Giralt S, Thall PF, et al. Maintenance therapy with low-dose azacitidine after allogeneic hematopoietic stem cell transplantation for recurrent acute myelogenous leukemia or myelodysplastic syndrome: a dose and schedule finding study. Cancer. 2010;116(23):5420-5431.

32. Mohamedbhai SG, Edwards N, Morris EC, et al. Predominant or complete recipient $\mathrm{T}$ cell chimerism following alemtuzumabbased allogeneic transplantation is reversed by donor lymphocytes and not associated with graft failure. Br J Haematol. 2012;156 (4):516-522.

33. Platzbecker U, Wermke M, Radke J, et al Azacitidine for treatment of imminent relapse in MDS or AML patients after allogeneic HSCT: results of the RELAZA trial. Leukemia. 2012;26(3):381-389.

34. Bug G, Burchert A, Wagner EM, et al. Phase I/II study of the deacetylase inhibitor panobinostat after allogeneic stem cell transplantation in patients with high-risk MDS or AML (PANOBEST trial). Leukemia. 2017 Jul 28. [Epub ahead of print] 